\author{
F. Manni \\ Dr. F. Manni, \\ Department of Theology \\ and Religious Studies \\ King's College, London. \\ E-mail: endorester@ \\ gmail.com
}

http://orcid.org/0000-

0001-7436-7735

DOI: http://dx.doi.

org/10.18820/23099089/

actat.v39i1.9

ISSN 1015-8758 (Print) ISSN 2309-9089 (Online)

Acta Theologica 2019

39(1):181-199

Date Published:

24 June 2019

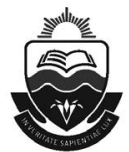

Published by the UFS

http://journals.ufs.ac.za/index.php/at

(c) Creative Commons

With Attribution (CC-BY)

OPEN ACCESS

\section{HERBERT MCCABE'S}

CHRISTOLOGY

\section{ABSTRACT}

Herbert McCabe wrote extensively about the classical topics of Christology, although his writings are scattered in many short texts. As for Incarnation, he holds both Bultmann's demythologisation and De Lubac's supernatural. Therefore, Chalcedon should be revised, not abolished, despite Bultmann, and the preexistence of Christ should be reinterpreted, not considered meaningless. As for Jesus' life, on the positive side, McCabe states that Jesus wanted to live a full human life and thus had to necessarily fight against the evils of a fallen humanity. On the negative side, McCabe intends to criticise some theological "nonsenses" such as God being within time and resurrection as a distinct chronological further step within a series.

\section{INTRODUCTION}

In this article, I want to show a remarkable theoretical achievement in the fields of Christology: How is it possible to demythologise Christology in depth, but remain faithful to the most classic of the classics, Thomas Aquinas, and the dogmas of magisterium. This was the achievement of Herbert McCabe, whose thoughts about incarnation and Jesus' life I present in this article.

McCabe does not speak frequently of Incarnation, even though he talks extensively about Jesus Christ. It was not his habit, nor was it in that era, to write systematic textbooks, as it was done until the fifties, and it would be recomposed to do later (Twomey 1976). As far as 
the Chalcedonian dogma is concerned, Williams $(2000: 86,92)$ expressed McCabe's attitude. The task of the theologian is not to defend a formula, but to help a critical way of worshipping and to keep alive the impulse that comes from these formulae. Thus, the Chalcedonian dogma must be viewed within the context of conversion. For McCabe, the Chalcedonian dogma, while warning us against blind alleys, must help us in our quest for Jesus, so that we can approach the mystery of God; but we should not worship the formula itself, which, instead, has to be deeply improved (McCabe 1987:74). Therefore, McCabe is not interested in filling the eight gaps that Sarah Coakley noticed in the Chalcedonian definition (2002:chapter 7); he had his own agenda, which was related more to the events of his times than to the history of the dogma.

\section{THE TRANSCENDENCE OF GOD}

A cultural event was the publication of the collective book The Myth of God Incarnate, published by John Hick in 1977. McCabe reviewed the book and, in New Blackfriars, publicly debated the topic with one of the authors, Maurice Wiles, who had responded to the review (McCabe 1987).

First, McCabe is keen to adjust the distances between him and his fellow theologians. On the one hand, he wants to tell them that he supports them, since he is a man of his century who is attentive to the results of contemporary culture and who also agrees that the dogma of Chalcedon should be greatly improved, thanks to the resources of contemporary culture. Furthermore, he mentions that the authors of The Myth of God Incarnate want to show that Jesus was fully human; they oppose Docetism, which is a good thing. On the other hand, he disagrees with them, because their anti-Docetism comes solely from $20^{\text {th }}$ century culture and mentality, not from tradition. Moreover, he finds it peculiar that these authors oppose Docetism and Incarnation. According to them, Incarnation is nothing but a myth (McCabe 1987:54).

Secondly, McCabe seizes the opportunity to carry out his, let's say, "Dominican" mission (contemplata aliis tradere), that is, to remind his colleagues, who are fattened on contemporary mentality, of the precious concepts of ancient and medieval philosophy. For example, reminding them that there cannot be natures not existing in reality (without "hypostasis", in the terms of Chalcedon), at least according to his "idealistic" interpretation of Aquinas, "the notion of an 'anhypostatic nature' just does not bear serious examination" (McCabe 1987:73). Another example is to recall the difference between "nature" and "person" (hypostasis): 


\begin{abstract}
Confusion arises about this from the muddled idea that a human nature ordinarily has a 'human sort of person' to sustain it or in which it can inhere, and that this sort of 'personality' is missing in Jesus and replaced by a divine kind as though the proper and appropriate hypostasis for a human nature were replaced by a divine one. But this all comes from forgetting what we use 'person' for; we use it to answer the question 'Who?' not the question 'What?'. No meaning can be attached to 'the appropriate kind of hypostasis for a human nature'; there are no 'kinds of hypostasis' except in so far as they have natures. In virtue of the incarnation, in virtue of assuming a human nature, the Son of God becomes a human person in exactly the same sense as I am a human person (McCabe 1987:73). ${ }^{1}$
\end{abstract}

Thirdly, McCabe wants to set his treatment of this dogma of revealed theology, using the concepts of his philosophical theology on the transcendence of God, that is, on how to understand firmly that God, being creator, is not part of the universe. Ombres, ${ }^{2}$ a long-time friend of McCabe at Blackfriars, recalls that one of the fixed points of McCabe's teaching and conversation was exactly this one, and how, according to McCabe, it could help in the intellectus fidei of the mystery of Incarnation.

In fact, how can the two natures of Jesus be united without contradicting and limiting each other? At first, McCabe notices that many Christians do not understand that God and man do not occupy the same space, different from a man and a sheep, which make two animals. What do a man and God make? Part of the meaning of "man" is that it is not another creature, but it cannot be part of it that man is not God. God is not part of the universe; he is not something you have to exclude if you want to know what a man is. We do not understand, of course, what it means for a man to be God, but it is not as contradictory as if we said that a man is a sheep. It is very mysterious, but "it is not flatly contradictory", because the human and the divine do not occupy the "same universe" (in fact, "the divine does not occupy any universe") (McCabe 1987:57-58, 47-48).

From this generic observation of "negative" theology we can argue, more specifically, against the so-called "pre-existence of Christ", a doctrine which apparently seems to want to safeguard the transcendence of God (the Son), but which in reality risks to put man and God on the same

1 Incidentally, I note that, almost using the same words, this distinction between "who" and "what" and the claim that the human "personality" of Jesus was not replaced by any divine quality or capacity, reappears in the recent article by McFarland (2014:150) to which I will refer later.

2 I interviewed Robert Ombres, former student of McCabe at Blackfriars Convent in Oxford, on 19 February 2016. 
worldly and temporal plane: "[T]here is no such thing as the pre-existent Christ". This doctrine - McCabe argues - was invented in the $19^{\text {th }}$ century to distinguish the eternal procession of the Son from the incarnation of the Son, by those who wanted to say that Jesus did not become the son of God because of incarnation, since he was already the son of God before it. But, if we speak of pre-existent Christ, we imply that God has a story other than incarnation: we imagine God living for ages before incarnation, like a man or another creature, and, at some point of his "career", he "becomes" man. But this is incompatible with the traditional doctrine about God as unchangeable. Eternity is timeless, but not like an instant that is a border between two times; it is beyond time. "To be eternal is to be God". God is not before or after or simultaneous with any event or history. The depiction of God becoming man is a powerful metaphor, but it is not literally true (McCabe 1987:49).

Therefore, there is not a "moment at which the eternal Son was not Jesus of Nazareth", because in God's life there are not moments. The eternal life of the Son does not precede or is simultaneous with his human life: "[T] here is not a story of God before the story of Jesus" (McCabe 1987:50).

Moreover, there is certainly a time when Jesus was not born. Moses could have said truly that Jesus does not exist (because the future does not exist), but Moses could also have said with truth that "the Son of God exists". That the two propositions are both true might be called the pre-existence of the Son, suggesting that, prior to Jesus' birth, we were allowed to make an apparent distinction between the Son of God and Jesus. But we were not. In fact, the phrase "pre-existent Christ" seems to imply that, at the time of Moses, the proposition "the Son of God exists now" is also true. But it is not true, because the "now" is temporal and the temporal existence of the Son of God became true only when Jesus was conceived in the Virgin Mary. McCabe maintains that, apart from the historical existence of Jesus, there is not any time when it is true that the Son of God exists (McCabe 1987:50).

McCabe mentions that those who did not think that God is not an inhabitant of the universe cannot understand that God does not pre-exist and that the Son of God does not pre-exist. Of course, nobody else can either, but, in the tradition, this is the mystery when we speak of God (McCabe 1987:50).

What consequences of some interest, if any, can come from these very abstract reflections? I will attempt to answer this question at the end of the section on Incarnation. I will now present what McCabe says about the two natures and the hypostatic union. 


\section{CHALCEDON REVISITED}

Although McCabe would have liked to change the terms of Chalcedon considerably, he continues using them (human and divine nature, personal union). However, he strongly emphasises that even faith in revelation does not allow us to know the divine nature of Christ. Following his mentor Victor White, McCabe maintains that the only knowledge we can have of Christ is of his human nature. When we think that we know what God is in himself because we know what (the fundamental qualities of) Jesus Christ is, we are wrong, since what we know and understand is simply his human and not his divine nature, as will be indicated below.

The revelation of God in Jesus in no way, for Aquinas, changes the situation. By the revelation of grace, he says, we are joined to God as an unknown, eiquasi ignoto coniugamur (McCabe1982:195; 1987:41).

For example, we do not know what the intra-Trinitarian relationship is between the Father and the Son. Both by faith and reason, we know Jesus' attitude of obedience to the will of God, and by faith, we hold that this "is just what the eternal procession of the Son from the father appears as in history" (McCabe 1987:23). He is of the opinion that a better understanding of Jesus' humanity will help us become aware of the mystery of God: that is, we can "understand" Jesus' humanity, but his divinity is a "mystery" (McCabe 1987:74). For instance, differently from his forebears, he considers that Jesus was a lot less self-consciously messianic; unlike scholars prior to the $20^{\text {th }}$ century, he opines that Jesus was fairly involved in the political turmoil of his times (McCabe 1987:73). But this improvement of our knowledge of Jesus' humanity does not involve a better knowledge of his divinity.

Thirty-seven years after the debate with Wiles and twenty-seven years after its re-publication in God Matters, a contemporary theologian, lan McFarland, resumes McCabe's observation and provides it with historical examples: perfect God consciousness (Schleiermacher), Jesus' intention to found the kingdom of God (Ritschl), refusal to claim any goodness for himself (Baillie), absolute subordination to the will of the Father (Pannenberg), and so forth. These Christologies share the same basic claim: Jesus' humanity is seen in what is average and every day, while the divinity abides in certain extraordinary qualities. But this temptation must be resisted, because we can only point to what is created, and those aspects are simply human, not divine. If we take the humanity of Jesus seriously, "no aspects of it can be treated as a proof or manifestation of his divinity". "None of them, taken singly or in combination, establishes that this person is the second Person of the Trinity", and whatever 
miracle Jesus performs, can also be performed by other human beings (McFarland 2014:49, 157).

McCabe already made this point clear: there are topics where historical research overlaps with the definition of faith (for example, if the archaeologists found the body of Jesus). But there are others where the research does not overlap (for example, Incarnation is not vulnerable, because it does not make statements about the human behaviour of Jesus or even "his inmost psychology" [McCabe 1987:69]).

On the other hand, what does the Incarnation tell us about the divine nature? First, to be divine is not to be a kind of thing; just as to be a creature is not to be a kind of thing (Manni 2017), whereas to be a man means to be a kind of thing, the one Jesus was (McCabe 1987:71). God is not part of the universe; he is not something you have to exclude if you want to know what a man is (McCabe 1987:57).

Thus, the two natures are not like an engine and a sail to provide movement to a boat, but they are two levels of speaking of Jesus. Or, a way to say that he exists on two levels (McCabe 2002:110). McFarland also follows McCabe on this point: Chalcedon states that Jesus is fully divine but, since the divine nature is invisible and ineffable, it cannot be shown; it is thus treated as an observable property of Jesus; in fact, any observable property of Jesus can be exhibited by other human beings. The divine nature in the mind of the Fathers of Chalcedon has qualities such as omnipotence, eternity and the like, but, for the very reason that they are super-human, Jesus cannot exhibit any of them in his human life. An impressive example is divine impassibility and how Jesus "exhibited" it on the cross (McFarland 2014:56).

McCabe's prevalent line is apophatic. Divine nature is not something that can be known by us, neither by reason, nor by faith. To us, Jesus' divine nature is not a series of qualities or ideas, but a relationship with us. When we study Jesus historically, we understand that he was a man and not an angel or a supernatural visitor; but we do not only study Jesus historically: we also listen to him, and this communication of his to our faith and his friendship with us is the other aspect or "nature" of his existence, his divine being.

The insight that Jesus was uncreated is available only to those in whom this rapport is established, to those 'who have faith in his name' (McCabe 1987:71).

The doctrine of Incarnation (like creation and redemption) does not convey information, but points to the mystery in Jesus: that Jesus was 
God does not tell us something about his life, but about the significance of his life for us (McCabe 1987:58). The hypostatic union appears only in the transformative relationship with the believer:

It is in the contact with the person who is Jesus, in this personal communication between who he is and who I am, that his divinity is revealed in his humanity, not in any, as it were, clinical, objective examination of him. Any such examination will simply reveal correctly that he is splendidly and vulnerably human (McCabe 1987:71).

The so-called communicatio idiomatum matters only for the believer who hopes for salvation and eternal life from Jesus, whereas it is useless for the non-believer, as McCabe summarises. According to Aquinas, it is one thing to say that God was nailed to the cross, and another to say that God "as such" was nailed onto the cross. When we say that God died on the cross, we do not mean the divine nature but the person who had that nature "in this case the man Jesus of Nazareth". Jesus was human and we can say that he was hungry; we cannot apply such predicates to a star. That he was divine allows us to say that he is creator, eternal son of God, omnipotent. According to the traditional doctrine, the two series of predicates apply to the same person referred to by the term "Jesus" (McCabe 1987:47). ${ }^{3}$ Since this person has two natures, we can qualify him with either human or divine terms; it makes no difference whether we call him Son of Mary or Son of God. In fact, it makes no difference in the subject part of the sentence. We may say that the friend of Peter sat down by the well, or that the Son of God born before all ages sat down by the well; the two "are exactly the same proposition" (McCabe 2002:108).

\section{THE PURPOSE OF INCARNATION}

In the traditional textbooks about Incarnation, one section is titled "On Christ's Predestination". It addresses the purpose of Incarnation and provides many different solutions throughout the centuries (Carol 1979). We know that, on this point, the Thomist McCabe takes sides with Scotists in favour of the "absolute" predestination of Christ: the purpose of Incarnation is independent from our original sin; Incarnation aims to deify us and free us from mere creaturehood:

Every student in a seminary is taught that to say that God spoke to the prophets is not to assert a change in God but in the prophets and that the incarnation is not an event in the history of God but of man.

3 In this instance, McCabe makes a mistake, because, according to Chalcedon, the "person", the "who" (hypostasis) is not an individual man, but the Word of God. 
The coming of the Spirit does not mean that God moves towards the world of man; it means that man is enabled to enter deeply into himself to know and love the divine reality which has been there all along (McCabe 1964a:26).

How, in particular? Jesus' life has its final meaning on the cross, showing how a human life reaches its purpose and finds its meaning in suffering "and that therefore God's love is expressed and enacted for us in the suffering of God" (McCabe 1987:87). As McCabe has repeated on many occasions in his works, Jesus wanted to be fully human, and, given the fallen world where we live, this was the reason for both his death and his resurrection, that is, of the particular shaping of his human nature, and of his belonging to the divine nature, which he wants to share with us.

Since, by Grace, divinity is shared with us, we are, therefore, part of the unique Incarnation of Christ. It is possible that, at present, another Christ incarnates in India, but what we expect to meet there is not "an alternative Christ but alter Christus"; that is, by Grace, we do not become extra incarnations of the Son of God but, by Grace, we belong to the one Incarnation of the Son of God, we are "in" Christ, according to St Paul (McCabe 1987:60).

How are we "in" Christ, though? It is important that the resurrection is bodily: it is Jesus, this "human bodily being who is risen. The resurrection does not cancel but rather crowns the incarnation, the enfleshing of the Word". It is not, say, that some inspiring memories of Jesus live in us. The message is that he has risen and lives with us. How? His bodily presence is "sacramentally" present "through a special depth in our intercommunion with each other. Christ is present but ambiguously present; what we see, the presence we experience, is the presence of each other" (McCabe 1987:110, 112).

McCabe focuses on the "body of Christ" of the Pauline teaching and strongly stressed by the Second Vatican Council in Lumen Gentium, where, for the first time in Catholic doctrine, the magisterium states that the "body" (the New Israel) is really the main interlocutor of God's action, which is addressed to his "people" and not primarily to the individual "souls".

\section{WHICH DEMYTHOLOGISATION?}

It is evident from the above that McCabe's Christology is situated within a progressive demythologising theology. For example, Bonhoeffer (1933:110) wrote that in humiliation Jesus is not more man and less God, nor in exaltation he is more God and less man. Always he is fully God and fully 
man. Lash (1992:80) held that in God we can see only Jesus Christ: if not, what other "aspects" of God could we see in God? In Jesus there is nothing missing, there is nothing more to see. McFarland (2104:151) maintains that the difference between Jesus and us is simply a "matter of predication", that is to say that this concrete set of human qualities, belonging to Jesus of Galilee, are "properly named as God's".

In fact, McCabe (1987:72) also holds that a human person is simply a person with a human nature and it makes absolutely no difference to the logic of this whether this same person does (as in Jesus) or does not (as in us) exist from eternity as divine.

However, like Bultmann or the authors of The myth of the God Incarnate, McCabe is not merely demythologising Jesus (and God). In fact, it is true that, from Bultmann and the like, he derived the fundamental notion that there are "traditions of men" to be distinguished from the commandments of God: specifically, the cultural habits of the $1^{\text {st }}$ century CE to resort to magic and marvels.

However, from De Lubac, he derived the fundamental notion that there are no two parallel realities, that is, the "natural" and the "supernatural". These are only two points of view. From the natural point of view, everything is natural (grace consists entirely in the external and internal events of the historical world), and from the supernatural point of view, everything is supernatural (every temporal space element of the world is created, that is, supported in existence by God).

Finally, in his own position as defender of the theological tradition of Augustine and Aquinas, McCabe wants to assert that there is a profound continuity in the truths that Christianity has developed over the millennia: Chalcedon should be revised, but not abolished, and, unlike Bultmann, the pre-existence of Christ, as we have seen, should be reinterpreted, but not considered "not only irrational but utterly meaningless" (Bultmann 1941:328). McCabe, instead, finds in it a meaning: the doctrine was invented to distinguish the eternal procession of the Son from the incarnation of the Son, by those who wanted to say that Jesus did not become son of God because of Incarnation, since he was Son of God "before" (independently from) it. Moses could not say with truth "the Son of God exists now", but he could say with truth "the Son of God exists". This means that the only temporal existence of the Son of God was during Jesus' life, but his eternal existence is not created, is not within creation, because it is in the Triune God. On the one hand, McCabe, like Bultmann, wants to "demythologise": God is not a powerful person acting within history. On the other hand, differently from him, he still relies on Chalcedon, on the God/Man and on 
the relevance of Trinity for Christianity, since the theology of Trinity started from the problem of the God/Man (Powell 2001:177).

It seems that, on this theological topic of Incarnation, McCabe's position stands out not because of his own original solutions, but because, as on many other occasions in his works, he wants to play the role of peacemaker between tradition and contemporary sensibility. This (to answer my previous question) is probably the main reason why he ventures into these abstract concepts that, in themselves, are of no interest to him.

\section{JESUS' LIFE AND DEEDS}

\subsection{Between Myth and Mystery}

Whereas he was much more interested in Jesus' life, McCabe talks about Jesus in a modern way, following the traditional line of showing why Jesus is of universal importance, but, unlike the ancient theologians, without reducing his particularity to get his universality (to quote Williams) (Bauckham \& Williams 1987:22-23). McCabe also faces all those contemporary challenges listed by Tanner (1997:247):

the loss of self-evidence or presumptive truth for Christian beliefs with the decline of the church's influence and the growth of secular societies; the emergence of disciplines (for example, historical methods) that operate independently of religious beliefs or norms; the contemporary imperative for respectful inter-religious dialogue; etc.

Like Bultmann and many other contemporaries, McCabe accepts the invitation to demythologise, and he never mentions a literal interpretation of the miracles of Jesus. In fact, to use the words of Bonhoeffer (1933:114-115), the miracles do not provide an inner conversion, "nothing happens in me if I assert my belief in miracles". Rather, contrary to the myth that seeks to decipher what is not comprehensible, McCabe adopts a "negative way", which, to quote Bonhoeffer $(1933: 114,77)$ again, states what we cannot say of Jesus: Jesus is a mystery, not a myth.

In his review of the popular bishop Robinson's book Honest to God, McCabe fully agrees with the author that we need to demythologise expressions such as "the descent of the Holy Spirit", or Christ "ascending into heaven and sitting at the hand of God the Father". In this instance, we see his characteristic concern for an innovation that does not forget the continuity with tradition: 


\begin{abstract}
If indeed it were not for his conviction that he is remodelling Christian ideas, what the Bishop has to say about God and Christ could be thoroughly acceptable to any traditional theologian. It might, again, be thought that someone who can present traditional Christianity as something new, fresh and revolutionary is doing a great deal and much needed service to the Church, but in fact the air of iconoclasm which the author evokes has merely led to his being interpreted in a non-Christian sense (McCabe 1964a:30-31).
\end{abstract}

Thus, the Jesus that emerges from McCabe's pages appears in this characteristic mixture of modern and ancient, of observations on the "imperialist colonialism of the Romans" along with quotations from the Council of Chalcedon.

\title{
6.2 Life of Jesus
}

Lash (1992:65) provides a good short definition of what the gospels are: good news of the risen one told as accounts of the earthly life of Jesus. The purpose is the transforming Grace onto the believer, but the actual content is Jesus' human life. According to McFarland, the gospel states that Jesus is the Word of God in order to identify Jesus as an individual person among the other individuals, not to explain his activities. Because of the hypostatic union, Jesus is "who" is and the Spirit makes him exist, but as for "what" he does, he relies on the gratia habitually granted by the Spirit like all of us. In fact, it is because of the Holy Spirit that each one of us is baptised, bears witness, performs deeds of power, and is raised from the dead. The Spirit in Jesus' life plays the role of making him human rather than distinguishing him from us (McFarland 2014:153-155).

McCabe already presented Jesus' life without any privileged features: there is no formula that summarises all Jesus and his mission. For example, Luke tells us about a boy who leaves his parents and that this is the beginning of his public life (a display of intelligence). However, in John's gospel, we see that, although Jesus was not interested in politics, politicians and other people of power were very interested in him (McCabe 2002:85). Another example: the fact that Jesus was without sin does not imply that he was "cold and inhuman, but rather just the opposite" - he was free and spontaneously able to love, not afraid of others (McCabe 2002:96). Moreover, Lash (1992:70) points out that the Nicene Creed, by not mentioning Jesus as a teacher, makes us aware that the gospel is not restricted to what Jesus said and that its central message is the announcement of the risen one. However, Jesus was indeed a Rabbi, who started preaching the coming of the "kingdom of God", continued teaching an original and profound set of ethics and, in his criticism of the religious habits of his times, was also 
a prophet who, according to McCabe $(1985: 8,12)$, was persecuted "for the sake of what is right", tortured and killed. They killed him, because he taught the people to live for each other and that they should set aside certain rules and laws (the tradition of men).

He was rejected, because he spoke with authority, believing that the relationship with him was more important than the ordinary people of God living according to the law, and this seemed like his monstrous egoism; he was at the same time threatening the religion and the priests' power within society. He ultimately died on the cross, because the people in power failed to recognise him as their saviour. However, their reluctance is not peculiar to them, but is fairly widespread, because each one of us finds it hard to accept what is truly human when we encounter it (McCabe 1987:90-91).

As for Jesus himself, he was not afraid to be human, because he saw his humanity simply as a gift from the one whom he called the "Father". He lived gradually exploring himself and asking the question: "Who do I say I am?" and, as an answer, he found nothing but the Father's love, that love that gave meaning to his life and is the meaning of the universe (McCabe 1987:95). In fact, if we as human beings are fortunate, we are often aware that we are loved. As Jesus grew up, he increased his awareness of being loved, and this is surely what shaped his idea of the Father. His teaching can be summarised as follows: he is loved by the Father and his followers are invited to partake of their love (McCabe 1987:95).

In his writings about ethics, McCabe opines that human life, by its very nature, is full of deadly anxieties that are contained and overcome when we feel a "security that comes from the certainty of being loved and accepted" and that Jesus was supremely open and unafraid; his ability to liberate others comes from "his unanxious, uncautious acceptance of them". From one point of view, this was his key characteristic: the capacity for friendship, for providing security so that people can accept themselves. Jesus knows that his security comes from his awareness of being loved himself. Therefore, the central fact about his "personality" is his capacity for love, whereas the central fact of his "person" is his being loved, that "he rose from the dead - that the love which sustains his personality brings him through death into life" (McCabe 1987:174). Then, this love is shared with us.

How? It is more a life experience than a matter of knowledge, for both us and Jesus. In fact, there is no God who is an item in the universe and "a rival person"; there is only the unknown beyond the universe and at the "heart of my being in Christ", says Thomas, we are united to God as to the unknown" (McCabe 1987:241). The Word of God is made flesh in Jesus 
not to keep us better informed: he does not give us new secrets; on the contrary, he shows our ignorance. In fact, Christians state that they do not know God. They know that they will be defeated by the powers of this world, but this does not matter much to them: because their faith is not in themselves, that is, in their understanding and in their success, their faith is in the power of God "and they know it is by accepting this darkness and defeat that they will get light and victory", as in the actual life of Jesus (McCabe 2005:141).

The "defeat", among other things, is death itself. McCabe's former teacher and fellow Dominican Ryan (2001:312) recollected some of his sentences about death in the speech he gave at his funeral:

\begin{abstract}
Herbert took the matter of death very seriously. "Death, which is the punishment of fallen man, has become, because of the Cross, the way to resurrection and new life". "The whole of life is a preparation for death because it is only from death that eternal life can spring". "For the humanist death is an irrelevant end-moment; for the Christian it is the beginning of true life, but only if it is accepted in total self-abandonment".
\end{abstract}

The "defeat" is also the cross. The cross, for both Jesus and us, is not a human achievement, even heroism; it is rather an absurdity; it is the ordeal of our being defeated and humiliated (Ryan 2001:312). Sometimes we try to put it in another way by describing Jesus as a winner who triumphs, if not politically, at least spiritually: he was a heroic martyr who triumphed over his persecutors with his calm resignation before death. But this is not true, because Jesus cried and sweated in terror in the Garden of Gethsemane: he was a failure and this is how he shows us the meaning of God, a meaning that we cannot understand (McCabe 2005:141). But, in this failure of his, we can find a constant travel companion who never forsakes us: whatever tragedy we have to face, Jesus is still there.

\title{
6.3 The resurrection of Christ
}

McCabe reminds us that, according to Chalcedon because of the communicatio idiomatum, we can literally state that God suffered hunger and death: the doctrine, while affirming that God is incapable of suffering, also states that God suffered in the same sense I suffer. One consequence is that we can say that God was nailed to the cross (McCabe 1987:46). "God was nailed on the cross and died", and his divine nature appears to the faithful by "God resurrecting him from this death".

What is the resurrection? Lash (1992:61) conveniently observes that there are so many different accounts of Jesus' resurrection that we cannot say: 
this is the meaning of the resurrection! We know that the resurrection and, for that matter, the ascension are not meant to be two separate events, but simply two aspects of the same destiny shared by Jesus and humankind. What destiny? McCabe (1987:109) recalls Jesus' words "whoever believes in me will never die" and, quite obscurely, adds that Jesus' resurrection is what the resurrection of humankind, the final consummation of human history - in itself an event outside history - will be when projected within history itself; in the same manner as the cross is what creative God's love looks like when projected onto human history, because it is the "sacrament" of the last times.

In somewhat clearer terms, McCabe (1987:106) denies that the resurrection is the last step of a series: passion, death, burial, resurrection. It is, instead, something on its own, the celebration of the meaning of the whole series: there is a passion play that re-enacts the events of the passion and another passion play that re-enacts the meaning thereof. Given the parallel with human history, could we say that, for McCabe, Jesus' resurrection is "outside" Jesus' life? Given the New Testament accounts and the tradition of faith, is the resurrection "spiritual" or "bodily" or both?

McCabe (2005:90) responds fairly obscurely to the first question: not only the ascension but also the resurrection is "into heaven", that is, Jesus did not resurrect into this world, and this heaven is not a kind of "spirit-world", but is a new world. He seems to say that the resurrection is not part of Jesus' life, not in the same series together with the other parts.

As for the second question, McCabe's answer is fairly contradictory. On the one hand, there are only two kinds of death: Christ's death, which is an operation of the Spirit, or the type of death that is simply the body ceasing to function (McCabe 2002:101). Thus, he seems to say that the humanity of Jesus may have been endowed with extraordinary attributes by the Holy Spirit, as opposed to the phenomenon of mere 'biological' death (bodily death, we could say). On the other hand, McCabe (1987:110) makes it clear that Jesus' resurrection is bodily and not merely an inspiring memory: the risen Christ is with us bodily. McCabe (1985:16) adds that Jesus' resurrection means that he was raised by the Father, that his body was not found in the grave and that he now lives a "human bodily life".

In summary: the resurrection is the "meaning" (therefore, as such, something "spiritual") of Jesus' life; but this meaning is embodied: Jesus is "with us" bodily. 


\subsection{Jesus Christ and us}

What is the presence "with us" of the resurrected Jesus Christ, before our death, after it and after our resurrection? Not surprisingly, McCabe (1964b:57) wants to emphasise a message that came to him from his Thomist education, from the Second Vatican Council and from the theological sensibility of his times, namely the importance of the body: we form part of the human species, because our bodies are linked to those of our ancestors; we belong to future humanity, because our bodies are linked with "the risen body of Christ". What could this "new humanity" be like? According to McCabe's anthropology, it should be a "united" humankind. This unity is to be achieved through the administration of the sacraments and by helping the poor, the two ways whereby we encounter the "risen Christ" (McCabe 1987:113). In fact, he rose from the dead, and through death he came to "a new kind of bodily life" with us. When we feed the hungry, "we encounter Christ, not in a metaphorical way, but literally" (McCabe 2005:40).

In a broader sense, we should maintain good interpersonal relationships. In fact, with regard to the ontology of the Eucharistic gathering, McCabe takes sides: the Eucharist exists qua sign of our unity: this is the reason why the body of Christ is here; he is present because of this, not the other way around. McCabe (1987:84) disagrees with those theologians who first look for Jesus' presence and then say that his presence is something we share, thus leading some people to think that his presence is somehow independent from the Mass, from the gathering of the faithful, as though the "great thing" was the consecrated wafer in the tabernacle.

However, after his resurrection, Christ is now present, but ambiguously present: the presence we directly experience is the presence of each other; after our resurrection, he will be present without ambiguity. In the meantime, his presence is also an absence: we proclaim your death, until you come again (McCabe 1987:112). It seems to me that, in this instance, McCabe is saying that our presence in the company of one another can be largely disappointing and that we may experience solitude, suffering and helplessness, even though we are provided with hope. A hope in the second coming of Jesus and his presence without "ambiguity", after "our resurrection", and, therefore, our death.

In the meantime, glimpses of a less ambiguous presence of Jesus - through the presence of other people - are possible, because human bodies are not only material objects, but also "means of communication". The risen Christ is seen only when he shows himself: we cannot imagine him being 
seen unawares. Moreover, even when he shows himself, he is recognised simply by faith; we need faith to recognise Jesus (McCabe 2002:220).

Despite the presence of the resurrected Christ, Christians cannot provide us with information about God, nor can they show us a way. Why? Because there is not any straight and settled road towards God. God is the thief at night, a lightning bolt. Even a purposeful type of communication such as preaching the gospel does not explain God to you, but rather makes you open, ready and receptive to the "sudden flashing" of the presence of Jesus, our God (McCabe 2005:144). We could now summarise McCabe's stance with regard to Jesus' presence:

- As the Word of God, he exists eternally, that is, out of time, which also means not "simultaneously" with us. His presence has something in common with, say, Pythagoras' theorem, which does exist, but is not really past, present or future in respect of our existence. It is "with us" like a non-empirical "truth" can be with us. This is the only kind of presence experienced by Moses and the others prior to Jesus' birth.

- "At the times of his flesh" in the company of Peter and others, Peter could then have said: this is his body. But in the days of his flesh, as happens to all of us, the body of Christ was also a "mode of absence, a limitation of presence", because our bodies are not merely a medium of communication, but also objects around us.

- After his resurrection, we can say "this is the body of Christ" with more depth than Peter, because now Christ is more "bodily" (more a medium of communication). When we feed the hungry, we can say that we encounter Christ literally, even though it is by means of faith. However, Christ, now that he has been resurrected, is but ambiguously present: the presence we directly experience is the presence of one another.

- After death: If contact with Christ must be mediated as a "special depth in our intercommunion with each other", it is difficult to see what kind of contact with Christ we may have after death.

- After our resurrection (and his second coming), he will be present without ambiguity. Jesus' resurrection (and presence with us) relates to Parousia, the last day, when we shall all share in Christ's resurrection. This last day will not be an event of history; rather the end of it: it cannot be more enclosed in history than creation is enclosed in time (McCabe 1987:109).

I must remind you at this point that, despite all these obscurities, McCabe adamantly asserts in his writings about anthropology and ethics that this new life is "ours" and not "mine", and that this "justice" of the 
"kingdom" is deeply connected with a ("revolutionary") victorious struggle for a better justice in this historical world.

Therefore, there is a double narrative in Jesus' life and deeds: a model for the life of the individual and a model for the destiny of humankind. Both narratives are good news. We can say that the Son of God was nailed on the cross, but not that the Son of God, as such, was (McCabe 1987:47). The story of Jesus is what "the trinitarian life of God looks like when it is projected upon the screen of history", actually the "sinful human history" (McCabe 1987:22). In other words, this double narrative is meant to make human beings relate to God and to Jesus as God, in other words, to a powerful positive meaning for their individual and collective life. To use Lash's (1992:65) words, Christianity "is a people with a memory and, for all the world, a hope".

\section{CHARACTERISATION AND CONCLUSIONS}

McCabe's depiction of Jesus' life and deeds distances itself from the wellestablished life of Jesus literary genre; it does not attempt to provide any new overall interpretation of Jesus. It is rather a matter of emphasis.

On the positive side, it tends to stress the necessity of Jesus' story: he felt that he was the beloved of the "Father", and, because he wanted to spread this love trying to live a full humanity, he necessarily had to fight against the wicked opposition of a fallen humanity. This positive side wants to understate any exceptional characteristic of Jesus, and emphasise a destiny shared with all of us: if you do not love, you cannot live; if you love enough, you will be killed.

On the negative side, McCabe, through his philosophy, intends to criticise certain theological "absurdities" such as God being within time (Moses cannot say "The Son of God exists now"); resurrection as a distinct chronological further step within a series; risen Christ's presence without a living community, and interpersonal presence without an intentional act of communication.

\section{BIBLIOGRAPHY}

BAUCKHAM, R. \& WILLIAMS, R. 1987. Jesus - God with us. In: C. Baxter (ed.), Stepping stones (London: Hodder and Stoughton), pp. 21-41.

BONHOEFFER, D.

1933. Christology. London: Wm. Collins. 
BultManN, R.

1941. New Testament and mythology. In: C.A. Evans (ed.), The historical Jesus: Critical concepts in religious studies. Volume 1 (Abingdon-on-Thames: Routledge), pp. 323-358.

Carol, J.B.

1979. The absolute predestination of the Blessed Virgin Mary. Marian Studies 31:180-187.

LASH, N.

1992. Believing three ways in One God. A reading of the Apostles' Creed. London: SCM.

ManNI, F.

2017. God as a creator according to McCabe. Divus Thomas 120(Sept/Dec):72-95.

McCABE, $\mathrm{H}$.

1964a. Dr Robinson's book. CrossCurrents 14(Winter):25-34.

1964b. The new creation. London: Continuum.

1982. A sermon for St Thomas. New Blackfriars 63(742): 193-195. https://doi. org/10.1111/j.1741-2005.1982.tb02536.x

1985. The teaching of the Catholic Church. London: Darton, Longman \& Todd.

1987. God matters. London: Continuum.

2002. God still matters. B. Davies (ed.). London: Continuum.

2005. God, Christ and us. London: Continuum.

McFARLAND, I.A.

2014. Spirit and incarnation: Towards a pneumatic Chalcedonianism. International Journal of Systematic Theology 16(2):143-158. https://doi. org/10.1111/ijst.12047

POWELL, S.M.

2001. The Trinity in German thought. Cambridge: Cambridge University Press. https://doi.org/10.1017/CBO9780511520198

RoBinson, J.A.T.

1963. Honest to God. London: SCM Press.

RYAN, C.

2001. Homily at Herbert McCabe's funeral. New Blackfriar 82(965-966): 308-312. https://doi.org/10.1111/j.1741-2005.2001.tb01763.x

TANNER, $\mathrm{K}$.

1997. Jesus Christ. In: C. Gunton (ed.), The Cambridge companion to Christian doctrine (Cambridge: Cambridge University Press), pp. 245-272. https://doi. org/10.1017/CCOL0521471184.015 
TWOMEY, J.

1976. "Whatever became of Adolphe Tanquerey?" The Furrow n. 9 (Sept), pp. 551-557.

WILLIAMS, R.

2000. On Christian theology. Oxford: Blackwell.

Keywords

Herbert McCabe

Christology

Apophaticism

Pre-existence of Christ
Trefwoorde

Herbert McCabe

Christologie

Apofatisme

Pre-eksistensie van Christus 